\title{
First record of Coronida glasselli (Stomatopoda: Coronididae) for Costa Rica (Isla del Coco National Park, Eastern Tropical Pacific)
}

\author{
Carolina Salas-Moya ${ }^{1,2}$ \& Rita Vargas-Castillo2,3 \\ 1. Centro de Investigación en Ciencias del Mar y Limnología, Universidad de Costa Rica, San Pedro, 11051-2060 San \\ José, Costa Rica; carosalasm@gmail.com \\ 2. Escuela de Biología, Universidad de Costa Rica. \\ 3. Museo de Zoología, Universidad de Costa Rica; ritavargas@ucr.ac.cr
}

\author{
Received 01-X-2015. Corrected 12-XI-2015. Accepted 18-XI-2015.
}

\begin{abstract}
Stomatopods are a small group of marine and estuarine crustaceans that inhabit several marine ecosystems including deep, shallow waters, and intertidal zones. Six species from five families have been reported from the Park. We add Coronida glasselli Manning, 1976 from rocky reef environments at Isla del Coco. In the Eastern Tropical Pacific the species was reported only from Isla Gorgona, Colombia. There are species from Isla Uva, Panamá in the National Museum of Natural History, Washington DC. Rev. Biol. Trop. 64 (Suppl. 1): S231-S233. Epub 2016 Febrary 01.
\end{abstract}

Key words: Reef, benthic invertebrates, stomatopods, diversity, Isla del Coco.

Stomatopods, also known as mantis shrimps, are an important group of benthic invertebrates with active predatory habits in temperate, subtropical and tropical waters. They are found from the intertidal zone to the deep waters of marine and estuarine ecosystems (Salgado-Barragán, \& Hendrickx, 2010).

A total of 35 species in 10 families of stomatopods have been reported for Costa Rica, twenty nine species are found in the Pacific Ocean and six species along the Caribbean coast (Vargas, \& Cortés, 1997; Vargas,
\& Wehrtmann, 2008; Vargas, 2009). In Isla del Coco National Park there are six species registered in five families (Table 1). The family Coronididae represents $5.7 \%$ of the diversity of the order in the country and is the most diverse family of stomatopods on the island, with two species previously reported, Coronida schmitti and Neocoronida cocosiana, the last one as an endemic species from Isla del Coco (Vargas-Castillo, \& Wehrtmann, 2008).

An individual Coronida glasselli was collected by scuba diving in 10 November 2014

TABLE 1

Stomatopod species reported for Isla del Coco by Vargas-Castillo \& Wehrtmann (2008)

\begin{tabular}{|c|c|}
\hline Family & Specie \\
\hline Coronididae & $\begin{array}{l}\text { Coronida schmitti Manning, 1976, } \\
\text { Coronida glasselli* Manning, 1976, } \\
\text { Neocoronida cocosiana (Manning, 1972) }\end{array}$ \\
\hline Gonodactylidae & Neogonodactylus zacae (Manning, 1972) \\
\hline Pseudosquillidae & Pseudosquillisma adiastalta (Manning, 1964) \\
\hline Squillidae & Crenatosquilla oculinova (Glassell, 1942) \\
\hline Tetrasquillidae & Tetrasquilla mccullochae (Schmitt, 1940) \\
\hline
\end{tabular}

* New report 


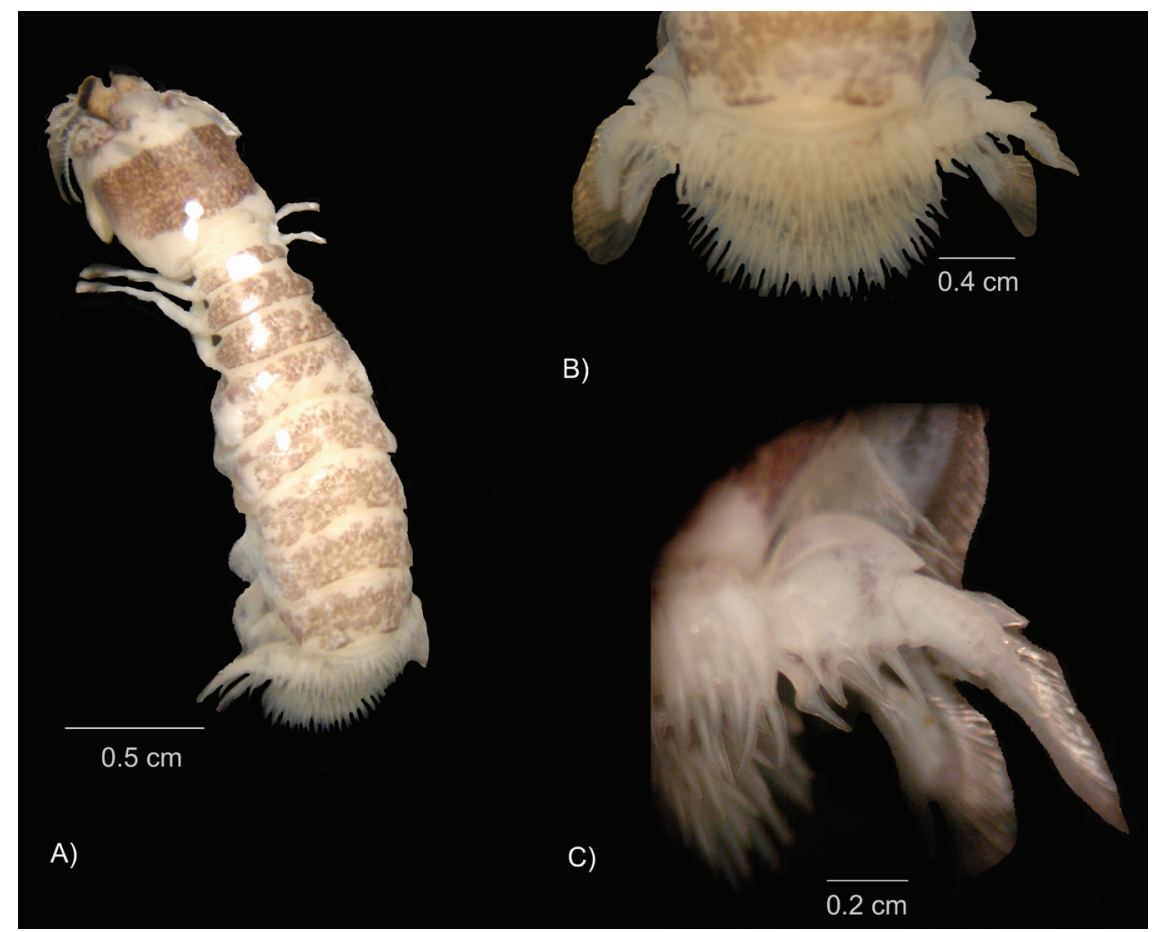

Fig. 1. Coronida glasselli Manning, 1976. (A) Specimen collected in Punta Ulloa, Isla del Coco National Park; (UCR 337801), (B) Telson detail, (C) Uropodal exopod thorns.

in shallow waters of Punta Ulloa, Isla del Coco $\left(5^{\circ} 33^{\prime} 23.13^{\prime \prime} \mathrm{N}-87^{\circ} 02^{\prime} 51.84^{\prime \prime} \mathrm{W}\right)$, at 6 to $12 \mathrm{~m}$ deep. This species was associated with coarse sand substrate in a coral reef environment. The organism was deposited in the carcinological collection of the Museo de Zoología (UCR 3378-01), Universidad de Costa Rica.

The present report of $C$. glasselli Manning, 1976 is the first record of this species on Isla del Coco. Coronida glasselli is a small species that has a total length of $3.60 \mathrm{~cm}$, with the sixth abdominal somite and the telson being covered by grouped thorns and less than 10 thorns in the basal segment of the uropodal exopod (Fig. 1) (Manning, 1976; Salgado-Barragán, \& Hendrickx, 2010). Coronida glasselli has been reported previously from Isla Gorgona, Colombia, between 10 and $13 \mathrm{~m}$ depth (Manning, 1976; Salgado-Barragán, \& Hendrickx, 2010). In addition, specimens from Isla Uva, Panama, found in sandy-bottoms, and coral substrates at $25 \mathrm{~m}$, are deposited in the National Museum of
Natural History, Washington, DC, but is unpublished (NMHH 2015).

\section{ACKNOWLEDGMENTS}

This paper was possible with the logistic support of Centro de Investigación en Ciencias del Mar y Limnología (CIMAR), Conservation International $(\mathrm{CI})$, the Undersea Hunter crew, and rangers from the Isla del Coco National Park. We are grateful to J.C. Azofeifa, S. Mena and J.M. Camargo for their collaboration in the field during the sampling. Finally, we want to thank J.J. Alvarado and C. Fernández for believing in undergraduate students' research and for the invitation to participate in the expeditions.

\section{RESUMEN}

Presencia del crustáceo Coronida glasselli (Stomatopoda: Coronidae) en el Parque Nacional Isla del 
Coco, Pacífico Tropical Oriental, Costa Rica. El orden Stomatopoda es un pequeño grupo de crustáceos marinos y estuarinos que habitan en una amplia diversidad de sustratos. En el Parque Nacional Isla del Coco se han hallado seis especies pertenecientes a cinco familias. El presente trabajo reporta a Coronida glasselli, el cual anteriormente solo se había reportado para Isla Gorgona, Colombia y en el Museo Nacional de Historia Natural, Washington, DC, se encuentran depositados individuos de Isla Uva, Panamá.

Palabras clave: Arrecife, invertebrados bentónicos, estomatópodos, diversidad, Isla del Coco.

\section{REFERENCES}

Manning, R. B. (1976). Notes on some Eastern Pacific Stomatopod Crustacea, with descriptions of a new genus and two new species of Lysiosquillidae. Proceedings of the Biological Society of Washington, 89, 221-231.
National Museum of Natural History (NMHH). (2015). Department of Invertebrate Zoology Collections. Retrieved from, http//:collections.nmnh.si.edu/ search/iz/?ark=ark:/65665/36ea2bd90-19b4-4cee$96 \mathrm{db}-6 \mathrm{f} 89 \mathrm{~b} 65 \mathrm{eb} 25 \mathrm{a}$

Salgado-Barragán, J., \& Hendrickx, M. E. (2010). Clave ilustrada para la identificación de los estomatópodos (Crustacea: Hoplocarida) del Pacífico oriental. Revista Mexicana de Biodiversidad, 81, 1-49.

Vargas, R. (2009). Stomatopods. In I. S. Wehrtmann \& J. Cortés (Eds.), Marine Biodiversity of Costa Rica, Central America (pp. 193-197). Berlin: Springer.

Vargas, R., \& Cortés, J. (1997). Biodiversidad marina de Costa Rica: Orden Stomatopoda (Crustacea: Hoplocarida). Revista de Biología Tropical, 45, 1431-1539.

Vargas-Castillo, R., \& Wehrtmann, I. S. (2008). Stomatopods and decapods from Isla del Coco, Pacific Costa Rica. Revista de Biología Tropical, 56(Supplement 2), 79-97. 
